\title{
HAUS Augmin-Like Complex Subunit 7
}

National Cancer Institute

\section{Source}

National Cancer Institute. HAUS Augmin-Like Complex Subunit 7. NCI Thesaurus. Code C113689.

HAUS aug min-like complex subunit 7 (368 aa, $\sim 41 \mathrm{kDa}$ ) is encoded by the human HAUS7 gene. This protein is involved in centrosome maintenance, mitotic spindle assembly and cytokinesis. 